\title{
Waste as a Resource: Form of Access and Conflict using Imported Waste in Sumengko Village, Gresik
}

\author{
Vil Laura Murdiahtin Ningsih ${ }^{1}$, Nindyo Budi Kumoro ${ }^{2}$ \\ \{doni.kumoro@ub.ac.id ${ }^{1}$ \} \\ Universitas Brawijaya, Indonesia ${ }^{1,2}$
}

\begin{abstract}
The issue of important waste entering Indonesia is now busy being discussed, the problem that occurred in Sumengko Village, Gresik. This problem stems from the disposal of waste produced by Adiprima, which is a paper factory that imports waste as one of its production materials. However, it is the valuable value of imported waste that makes waste a resource for them. The profit from this imported waste business makes actors want to get access to garbage. This seizing access then causes conflict between the actors involved, which ends in garbage news from the village.
\end{abstract}

Keywords: Garbage, Imported Waste, Trash Access, Conflict, Resources

\section{Introduction}

Recently, several cities in Indonesia have received attention from the national community to several academics, regarding the entry of imported waste products from several foreign countries. This is interesting to study further, because the waste problem in Indonesia alone has not been fully resolved by the government and society. Because if this problem is ignored, over time Indonesia can become imported trash cans. Quoted from Kompas.com, launching the coverage of VOA Indonesia in early 2019, Executive Director of Ecoton (Institute for Ecological Studies and Wetland Conservation), Prigi Arisandi, has conducted observations in villages where plastic waste is dumped in Mojokerto, Sidoarjo and Gresik. From these observations, it is known that more than three hundred containers transport plastic waste to East Java every day [1]

Imported waste delivery is due to paper factories ordering waste for production needs, but other types of waste are also carried away. According to the Times Indonesia, it is stated that in the import of paper raw materials, thirty to sixty percent of plastic waste is inserted [2]. This figure is quite large considering that the waste problem in Indonesia cannot be properly addressed, and its impact can pollute the environment. However, behind the disadvantages of imported waste, there are several people who benefit from its presence. As that occurred in the village Sumengko Wringinanom District of Gresik, the community trades imported waste purchased from a paper factory next to the village. This is based on the profit of buying and selling waste. For example, a resident who also works as a scavenger stated that the results from scavenging garbage are as much as fifty thousand to one hundred thousand rupiah, so that if calculated a month's income is as much as one million five hundred to three million rupiah. Based on this profit, it is not surprising if there are more than a thousand residents who participate in scavenging. This number could increase because there were residents from outside 
village also took part in scavenging. From this it can be seen that waste is not always viewed negatively and as useless by several groups of society.

The formulation of the problem in this research is why waste becomes something valuable for society? What is the community's view or understanding of waste? And what are the social implications of waste on society? The purpose of this research is to be able to find out more about the understanding of waste in the field of anthropology, to know more about the value of waste in society, and what factors make waste have an important value for a society.

This study uses the ethnographic method, namely, making regular observations of the behavior of the members involved, listening to and engaging in daily conversations, interviewing informants on problems that (maybe) are not directly related to observation, collecting documents about the group, develop an understanding of the culture of the group and the behavior of people in that cultural context, and write a complete report of the social environment they observe [3].

\section{The Beginning of Waste Collecting Culture in Sumengko Village}

Sumengko Village, Wringinom Subdistrict, is one of the villages where there are indications of imported waste in Gresik City. The village consists of five hamlets which are located adjacent to Adiprima (paper factory) including Sidotompo-Sidomoro Hamlet, South Sumengko Hamlet, Krajan Hamlet, North Sumengko Hamlet and Perdukuhan Hamlet. Geographical location is also adjacent to several other factories (metal factory, ceramic factory, corn factory and tofu factory). This affects the majority of its citizens as factory workers. The reason why residents choose this profession is because factory workers' salaries in Gresik are the second largest in East Java. Based on the Tribunnews page, the highest UMK Gresik in 2018 is IDR 3,580,370.64, this figure is almost the same as the UMK Surabaya [4].

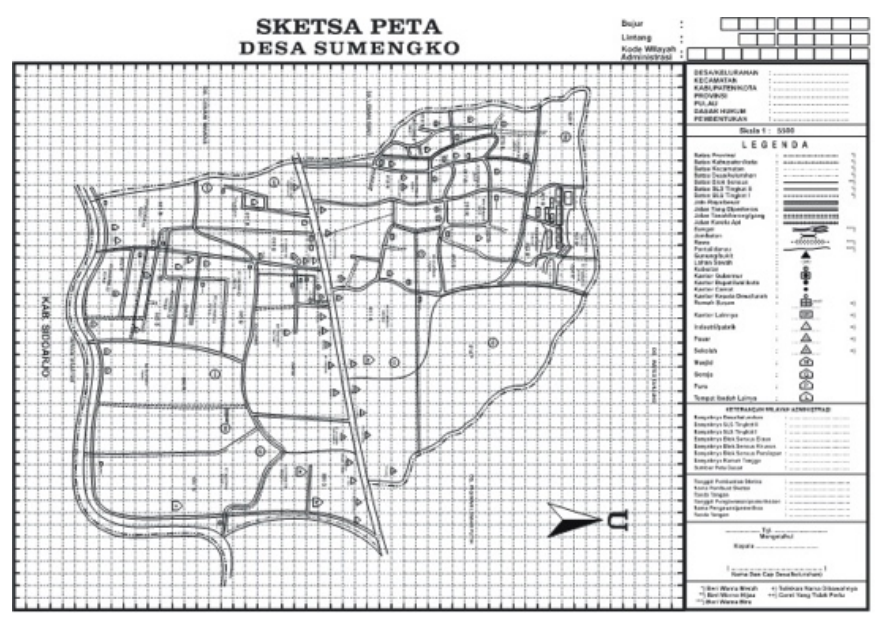

Fig. 1. Map of Sumengko Village (Source: www.gresikkab.go.id).

Until 2009, imported waste began to come to the village. Incoming waste is Adiprima production waste, namely a factory that imports paper waste for production needs. But what Adiprima needs is only paper waste for the mixture of raw materials, while other types of waste 
are not needed and are eventually disposed of in the nearest village. The arrival of the trash makes changes, either directly or indirectly. Such as changing residents' jobs and views on waste. So, what was the condition of the village before the trash arrived? Village roads are still rocky; flooding caused by overflowing river water and empty land converted to plantations are conditions in the village before the entry of imported waste. According to Mr. Wasik, before the arrival of the garbage, the residents worked as farmers or farm laborers. Although now, few residents work as farmers or farm laborers, because the rice fields have been converted into factory land.

The beginning of the arrival of garbage is due to the role of several actors who want to take advantage of the waste benefits; they are residents of Sidotompo Hamlet. According to the statement of Mr. Saceng as a resident of Sidotompo Hamlet, he said that each hamlet received waste from Adiprima, especially in Sidotompo-Sidomoro Hamlet, which received more waste than other hamlets. It is because of the location of the village which is adjacent to the Adiprima, it does not directly matter is also stated that Adiprima is the only actor who import garbage to the need of production. This is existence of dumping garbage into the hamlet is certainly giving advantage to Adiprima, for getting land to accommodate the waste they are already mounting. So, it can be said that the condition is mutually beneficial for both (Adiprima and residents of the village).

"If we look further, this incident is not entirely the fault of the factory that disposed of the waste, because the residents themselves asked for the waste to be disposed of. Meanwhile, the factory does not own land that is used for their waste disposal", said Ayu a village secretary.

So, it is not surprising, if in Sumengko Village in a day, a landfill can receive two to five containers of garbage. If there are four dumpsites in a hamlet, then one hamlet receives eight to twenty containers of garbage every day. If in one container load of garbage by weight of 29 tons, the amount of weight of the garbage that is dumped in a day as much as 58-145 tons. While the amount of weight garbage that dumped at four land disposals in a day as much as 232-580 tons. Weight is not reduced by the garbage that was purchased by small collectors, that where usually buy one container every day.



Fig. 2 Garbage disposal area. 
There are four landfills in Sidotompo-Sidomoro Hamlet, which belong to residents or government-owned land which is converted into landfill. In those four fields, I still found imported plastic food wrappers, which were considered worthless waste for collectors and scavengers. According to Mr. Wasik and Mr. Cokro as import waste scavengers, they stated that the garbage that comes to the village comes from various types of the world. However, according to the Ecoton study, there are more than 50 brands of plastic waste originating from more than 20 countries in Europe, Australia and Asia [5]. In this pile of garbage, the villagers start sorting out rubbish that has valuable value or that can be reused.

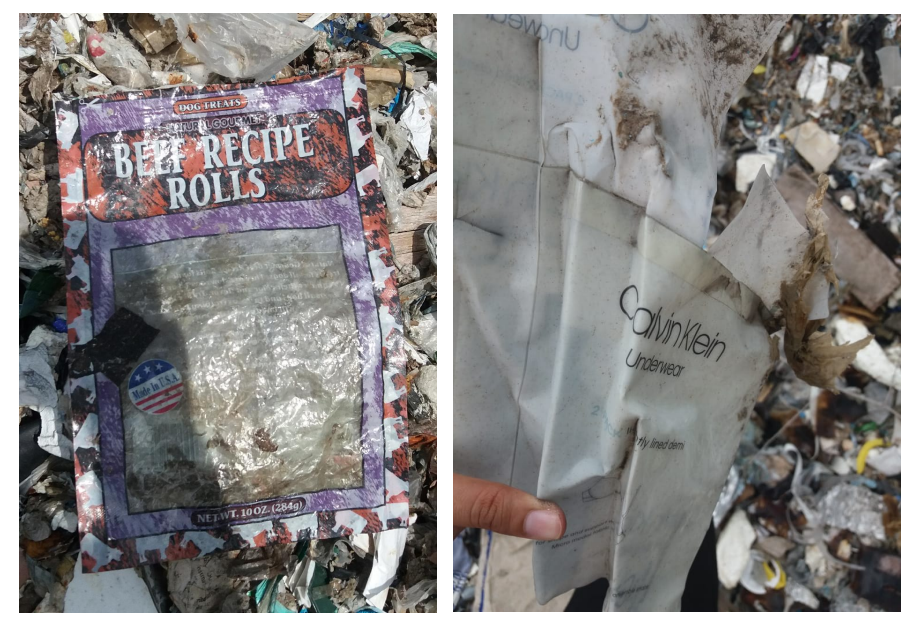

Fig. 3. Example of imported waste

Due to the satisfactory profit, many residents also work as collectors and scavengers. Mr. Saceng mention that for one container of garbage to get a profit of one million in a day, this amount may increase considering there are more than two container trucks that throw garbage into the village every day. The type of waste taken by residents is not only plastic waste. However, trash that can be used again, such as gold, foreign currency, cutting boards, knives, scissors, spatulas, and metal bowls.



Fig. 4. Foreign money found by residents (Source: Taken by Mbak Yanti). 
With the existence of these two types of waste (gold and money), it is not only residents who participate in hunting for imported waste. Adiprima employees also hunted both types of garbage. Mr. Wasik and Mr. Abdullah stated that not all employees had the opportunity to sort waste. Only a few employees placed in the department of managing imported waste can do this.

\section{Valuable and Non-valuable Waste}

The reason residents prefer imported waste to local waste is that it is clean in quality and has a high selling value. Mrs. Sulami, as a sorting agent for imported waste, stated that it is easier to sort imported waste than local waste. From the four dumps that I have visited, I found that the pile of garbage is not only dominated by plastic or aluminum. However, clothing, rolls of paper, sandals or shoes, underpants, gold and foreign currencies were also found.



Fig. 5. Waste sorting processes.

Mr. Saceng, a small landless collector, stated that imported waste is much more profitable and easier than local waste. Since he doesn't need to look for raw materials, waste is sent daily by Adiprima. Moreover, the price is much cheaper and quality is much better than local waste. Local waste will be sold per kilogram (kilonan), while imported waste can be sold by kilonan or per truck. Per kilogram (kilonan) purchase usually apply to dry waste, while per-dum truck purchases apply to wet waste.

Advantages of garbage are also felt by the scavenger imports. Mrs. Yanti, who is the one of the scavengers she said, was happy with her scavenging activity. She mentioned that did not feel tired at all even though the sun was hot and the smell of garbage was strong. Mr. Wasik also mentioned that search for garbage is a means of building kinship. Because there is no competition about who finds the most or the fastest waste, all scavengers seem to encourage on another. 


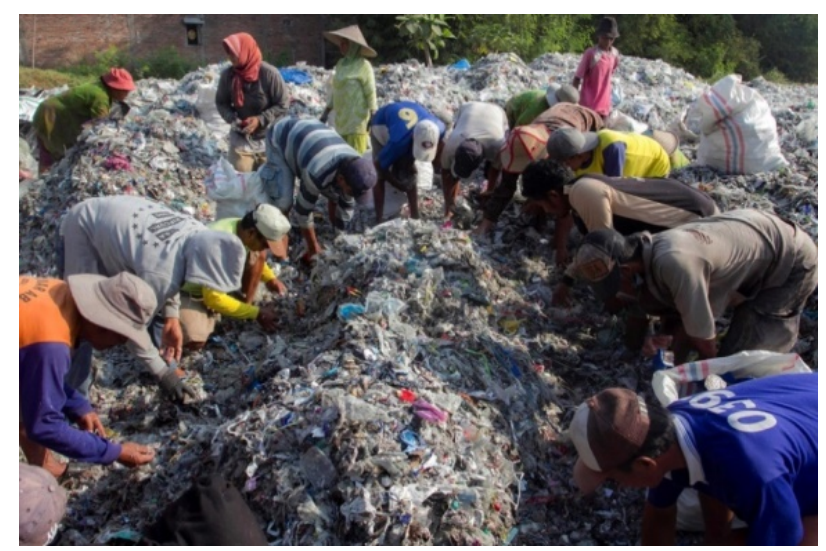

Fig. 6. Search for imported waste by scavengers (Source: Taken by Syafi/beritagar).

After the search process, scavengers immediately bring the garbage home, then sort and categorize which ones are valuable and which are not. The valuable waste will be collected for a week before being sold to collectors. In a week Mr. Wasik can collect as many as four to five bags of aluminum (almini), weighing seven kilograms. The proceeds from sales are eighty-four thousand rupiahs, so that in a month they can generate money as much as two million five hundred and twenty thousand rupiahs. This figure can go up and down according to the selling price of waste from collectors to the company. The definition of valuable waste not according to scavengers and collectors is different; this is due to the different reasons for finding waste. Scavengers usually pick up trash from the land and process it at home, while collectors collect and process garbage in their warehouse. With this they will have more freedom to process and sort out valuable and non-valuable waste, which is based on the sale value. Mr. Saceng stated that waste that has a selling value will be immediately sorted and processed to be sold to the company. Meanwhile, waste that does not have a selling value will be burned immediately so that it does not fill the warehouse. The scavenger also picks up the trash with a function value.

Garbage that has been picked up by collectors is then categorized based on the type with different materials. For example, Mizone (one of the brand isotonic drink) and plastic color blue that has a material and color are different. If Mizone had the color blue transparent, while plastic color blue which usually consists of a plate of plastic, basin or bucket that has the color dark blue. It is also that apply to the types of garbage more. Their categorization of trash is easier for the mediator in the processes of production.

Categorization of waste that is valuable and not according to collectors:

\begin{tabular}{|c|l|c|c|c|c|}
\hline No. & \multicolumn{1}{|c|}{ Types of Trash } & Garbage Category & Price 1 Kg & Valuable & $\begin{array}{c}\text { Non- } \\
\text { valuable }\end{array}$ \\
\hline 1. & LDPE white slab & $\begin{array}{c}\text { Ale-ale (one of } \\
\text { the brand drinks taste) }\end{array}$ & Rp. 7,300 & $\sqrt{ }$ & - \\
\hline 2. & PP red & $P P$ abang & Rp. 7,100 & $\sqrt{ }$ & - \\
\hline 3. & PP blue & PP biru & Rp. 7,100 & $\sqrt{ }$ & - \\
\hline 4. & PP green & PP ijo & Rp. 7,100 & $\sqrt{ }$ & - \\
\hline 5. & PVC transparent & Blowing aki & Rp. 8,500 & $\sqrt{ }$ & - \\
\hline 6. & HDPE & PP tembok & Rp. 9,500 & $\sqrt{ }$ & - \\
\hline 7. & PP black & PP ireng & Rp. 5,700 & $\sqrt{ }$ & - \\
\hline
\end{tabular}




\begin{tabular}{|c|c|c|c|c|c|}
\hline 8. & PP white & PP tebel & Rp. 9,500 & $\sqrt{ }$ & - \\
\hline 9. & Beverage cans & $\begin{array}{c}\text { Almini } \\
\text { (aluminium) }\end{array}$ & Rp. 12,000 & $\sqrt{ }$ & - \\
\hline 10. & $\begin{array}{l}\text { Milk cans and other } \\
\text { types of metal }\end{array}$ & $\begin{array}{l}\text { Kaleng } \\
\text { (Cans) }\end{array}$ & Rp. 500 & $\sqrt{ }$ & - \\
\hline 11. & $\mathrm{CD}$ & $\mathrm{CD}$ & Rp. 10,000 & $\sqrt{ }$ & - \\
\hline 12. & $\begin{array}{l}\text { Close the gallon of } \\
\text { water }\end{array}$ & $\begin{array}{c}\text { Tutup galon } \\
\text { (close the gallon of water) }\end{array}$ & Rp. 7,500 & $\sqrt{ }$ & - \\
\hline 13. & Bottle cap & $\begin{array}{l}\text { Tutup botol } \\
\text { (bottle cap) }\end{array}$ & Rp. 7,500 & $\sqrt{ }$ & - \\
\hline 14. & ABS & Kerasan & Rp. 2,000 & $\sqrt{ }$ & - \\
\hline 15. & PET blue & BM biru & Rp. 4,800 & $\sqrt{ }$ & - \\
\hline 16. & PET white & BM putih & Rp. 5,200 & $\sqrt{ }$ & - \\
\hline 17. & PET plastic cups & $\begin{array}{l}\text { Aqua putih } \\
\text { (one of the brand plastic } \\
\text { cup of water) }\end{array}$ & Rp. 10,000 & $\sqrt{ }$ & - \\
\hline 18. & $\begin{array}{l}\text { Mizone } \\
\text { (one of the brand } \\
\text { isotonic drink) }\end{array}$ & Mizone & Rp. 3,200 & $\sqrt{ }$ & - \\
\hline 19. & $\begin{array}{l}\text { Sprite } \\
\text { (one of the brand soft } \\
\text { drink) }\end{array}$ & Sprite & Rp. 3,200 & $\sqrt{ }$ & - \\
\hline 20. & Other (polycarbonate) & BS kaca & Rp. 12,000 & $\sqrt{ }$ & - \\
\hline 21. & HDPE gallon & PS galon & Rp. 2,300 & $\sqrt{ }$ & - \\
\hline 22. & LDPE food wrappers & PP lit & Rp. 1,600 & - & $\sqrt{ }$ \\
\hline
\end{tabular}

PP lit waste is called collectors as worthless waste, because the weight of the waste is very light, so it takes a large amount to reach one kilogram. The garbage collectors choose to burn this garbage, this is done so that the garbage does not fill the warehouse. Tofu factories need this type waste to be used as raw material for combustion.



Fig. 7. Example of pp lit waste (Source: Taken by Petrus Riski/VOA).

There is also valuable waste according to scavengers but not to collectors, namely, clothing waste. Scavengers usually immediately bring home clothes that are fit for use to be washed and 
then reused. Mentioned by Mr. Wasik that many small children aged three to five years also used clothes made of trash. Unlike scavengers, collectors prefer to burn them because clothing waste is considered to have no selling value.

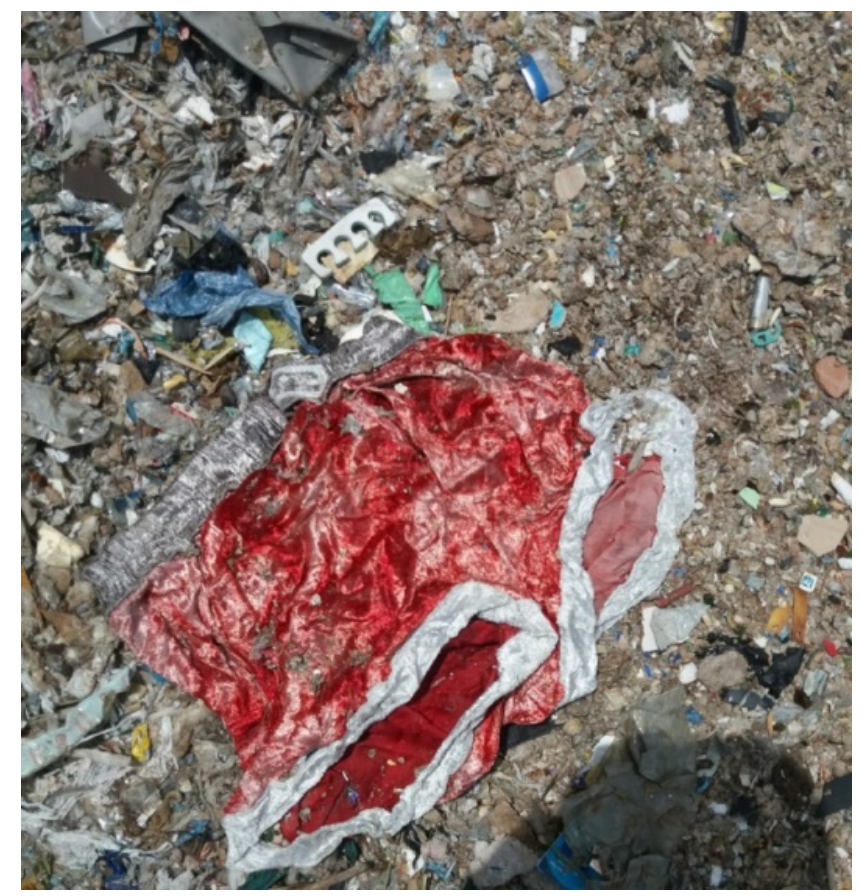

Fig. 8. An example of a shirt image found in a landfill.

In addition, there are two types of waste that are both taken up by both of them, namely, gold and foreign currency. This waste attracts the attention of residents from outside village to participate in collecting waste. The gold waste is immediately washed by scavengers and then sold to gold buying and selling shops in the nearest market. As for foreign currency, it is usually collected first by scavengers, and then exchanged for the skipper in the hamlet. The foreign currency exchange system is that the skipper will deduct the profits from the exchange for himself. The two types of waste that the inventors were always proud of did not have a big profit. Even finding this garbage is quite difficult; it is different from when the garbage was first dumped in the hamlet.

All types of waste are taken and then going through the treatment process that varies depending on the kind. This is different from the laundered and immediately sold foreign currency and gold waste. Other types of waste go through a fairly long process, namely categorization, milling, washing, and sale. Mr. Saceng mentioned that all types of waste can go through a milling process except cans and cables. The milled waste is an order from the company, usually the drinking glass waste that is often ordered. The process of milling waste is carried out directly at the collection point. 




Fig. 9. Waste milling processes.

The process of milling the waste can take up to a full day. Rubbish that has been milled is put into a sack and then certain codes are written which means where the waste will be sent and the type of waste. The delivery of garbage to the company was carried out by Mr. Saceng, because the location of the delivery was not far and the weight of the waste was quite light.

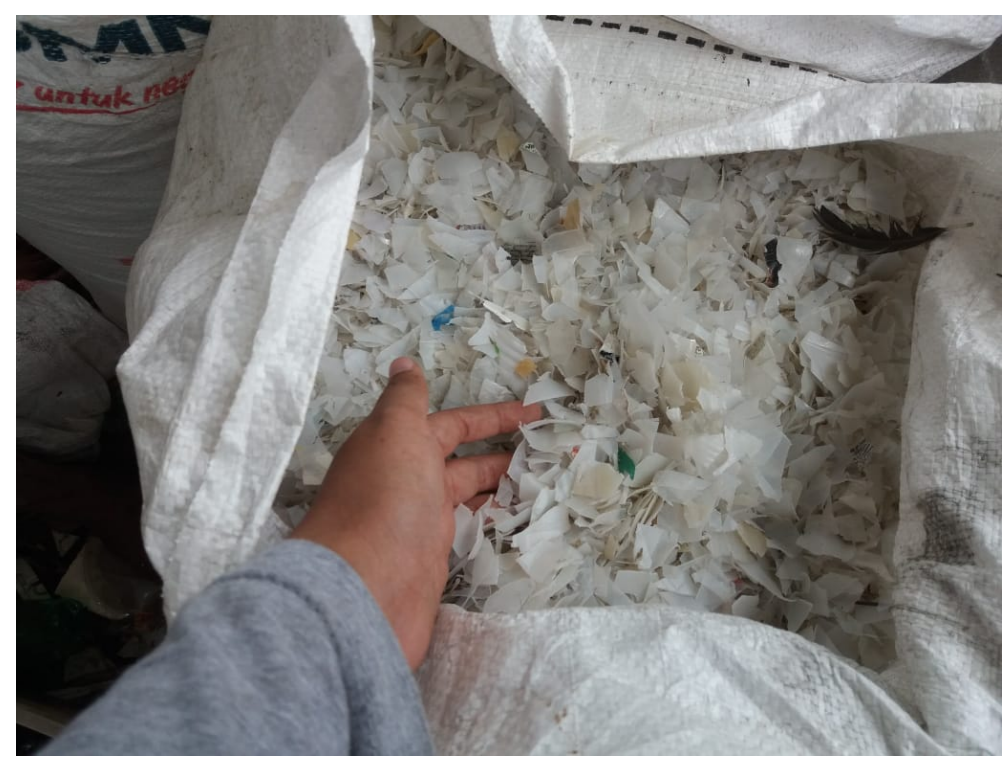

Fig. 10. Example of waste that is ready to be sent to the company. 
Location sending garbage to the village of Krikilan District of Driyorejo, it takes about forty-five minutes to get to the distributor locations using a pickup. Mr. Saceng said that the location of the distributor is always adjacent to the factory or company, so as to reduce the time for delivery of production raw materials. When the garbage sacks arrived, the workers immediately took down the trash using sickles. When the garbage is lowered, it is immediately weighed to determine the weight of the waste. Then the admin (the person in charge of supervising and making payments) pokes the sack filled with garbage using a pipe with a sharp tip. This is done to find out whether the waste carried is mixed with other types.

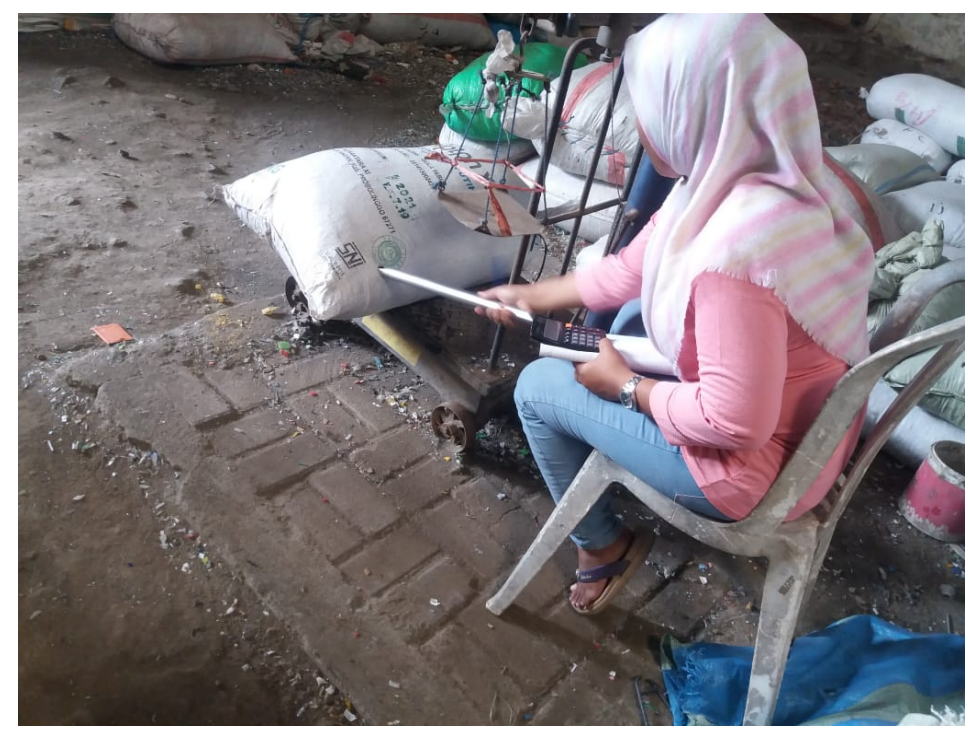

Fig. 11. Sampling process by admin.

Then each waste sack was sample as much as the container used for wall paint. Then the sack is written with a combination of numbers and letters which indicates how much the waste weighs and the type of waste. Finally, the waste payment is made by the admin, including a note as proof of the collector's transaction to the distributor.

\section{The Conflicts of Waste in Sumengko Village}

The advantages of the waste business make people feel comfortable working as scavengers and collectors. This is the reason why many people want to access garbage in the hamlet. The role of the actor who succeeded in obtaining claims for waste disposal, then earned him power over the sale of imported waste to other collectors. This is also used as a reason for conflicts between actors and residents or other collectors who want to access it. As stated by the residents of Sumengko Village, the arrival of garbage to the village can be traced to the role of a resident named Bilal. He is a resident of Sidotompo Hamlet who previously worked as odd jobs. Mr. Hari mentioned that he sometimes worked as a construction worker in the neighborhood from other villages. Then he found out that Adiprima trash has a high selling value, he got this information from one of the collectors from another village. 
According to Mr. Toni, a member of Ecoton, that dumping waste into the hamlet has the role of two actors, namely the residents and the Adiprima, both of whom are in a position of needing each other. Because it needs access to waste to generate profits and Adiprima needs land for waste disposal. As stated by Ribot and Peluso [6] that, access is about all the ways that allow a person to benefit from various things including material objects, people, institutions, and symbols. The use of this access applies to resources that are considered valuable by community groups. So, it takes strengths to make it easier for someone to access it.

One of the Adripima workers who is also a resident of Sidotompo Hamlet told Mr. Bilal that Adiprima has an abundance of garbage. Then he arranged a plan with his friends who were called thugs to establish a relationship with Adiprima. Residents call them thugs because they often commit violence against residents who are reluctant to sell their trash to them. Actions tend to lead to thuggery, making residents define them as thugs. Based on the Indonesian dictionary which defines the word thuggery, the characteristics of people who like to extort and commit crimes [7].

So how did he establish relationships with thugs? With the trust that Mr. Bilal built in his subordinates by the lure of a profit from selling waste. The concept of social capital in the study in economics says that the core of social capital of trust is the cultural dimension of economic life that determine the success of economic development. The existence of mutual trust is a very important lubricating element for cooperation [8] or in Putnam's terms [9] an attitude of mutual trust smooth social life. According to Putnam [9], social capital is a "public good", not the private property of those who benefit from it. The existence of social capital such as mutual trust, norms and networks, which tend to be (self-reinforcing) and cumulative. Subordinates who work on the basis of belief (trust) also have power to commit violence; this is makes residents do not want to have anything to do with Mr. Bilal.

Mr. Saceng explained that it was Mr. Bilal who planned with his friends to pick up necessities from the factory. Then he came with the intention of helping to solve the problem. There was communication between Mr. Bilal and Adiprima regarding this matter which then referred to the request for garbage disposal. This is what makes residents believe that Mr. Bilal plays a role as a pioneer and in control of the disposal of imported waste. The relationship that exists between the two results in a well-realized access to Mr. Bilal's trash. This is evident from the different amounts of waste shipments from other collectors. Other collectors receive one to two garbage trucks per day, while Mr. Bilal receives three to four garbage trucks per day. This comparison made him more profitable. Indirectly, he needs a large area to accommodate garbage. Initially he rented land for a landfill, which he later bought. The profit that Mr. Bilal gets is three million to four million rupiah per day; this does not include the profit from selling garbage to other small collectors. 


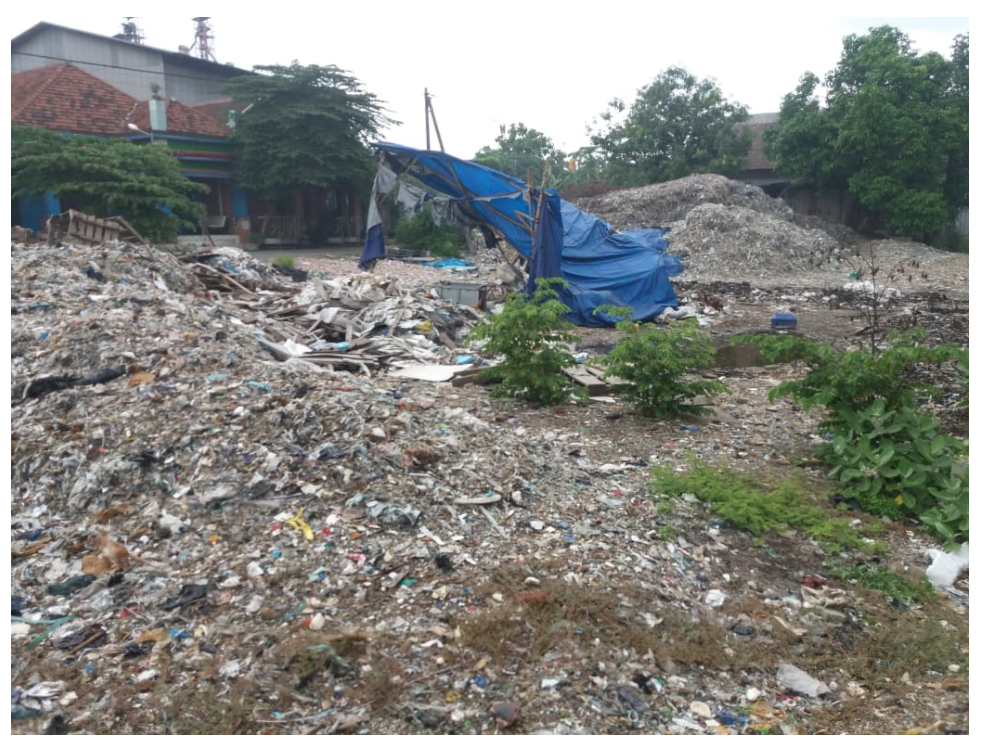

Fig. 12. Mr. Bilal's dumpsite.

Adiprima never sells waste produced to residents, but collectors who own land like $\mathrm{Mr}$. Bilal can sell garbage to other collectors. The price of garbage sold is three hundred and fifty thousand rupiah per truck. From this it can be seen that there is a patron-client relationship between Mr. Bilal and the residents, in which the patron (Mr. Bilal) provides resources in the form of waste to clients (residents or small collectors) which will later be processed and sold back to the patron. According to the journal written by Ellen and Hikmah [10], the patron-client relationship is ingrained and transformed in various forms with various variations and subordination of the patron to the client. Patron hegemony is an important key in the survival of the patron-client relationship pattern. The increasingly rampant patrons continue to increase capital (wealth), with capital and networks with an exponential increase in wealth. On the other hand, the client is getting stuck or even comfortable with a range of guarantees given patron, so that the state of the relationships makes them not able to improve the welfare significantly. Moreover, the mindset of refusing a patron's request will make the client's situation less likely to be safe.

The benefits that were obtained by Mr. Bilal caused resentment from the residents towards him. So how do people express it? The residents could not do anything and only expressed their dislike for other residents. Because residents still need access to imported waste from him. This form of resistance is the same as stated by Scott [11] which describes the dominating relationship between subordinates and superiors, which is known as public transcript and hidden transcript. Public transcript is the attitude of subordinates who seemingly obedient to superiors who dominate subordinate, whereas in fact harbored a sense of humiliation and a sense of want to rebel. While the hidden transcript is an attitude that is different from subordinates when being in front and behind the boss who dominates. Scott [11] also stated that the public transcript and the hidden transcript can have an impact that emerged in the public about the boss who is dominating. From here can be known how the picture of the relationship that exists between Adiprima, the owner of the land, the mediator large, small collectors, a scavenger, sorting trash and plant out. As well as a description of the conflict relationship that exists 
between Adiprima, Ecoton, village institutions and residents who work as scavengers and collectors. The conflict relationship is based on the impact that occurs after dumping waste into the village.

Chart relationships between actors are associated with garbage imported:

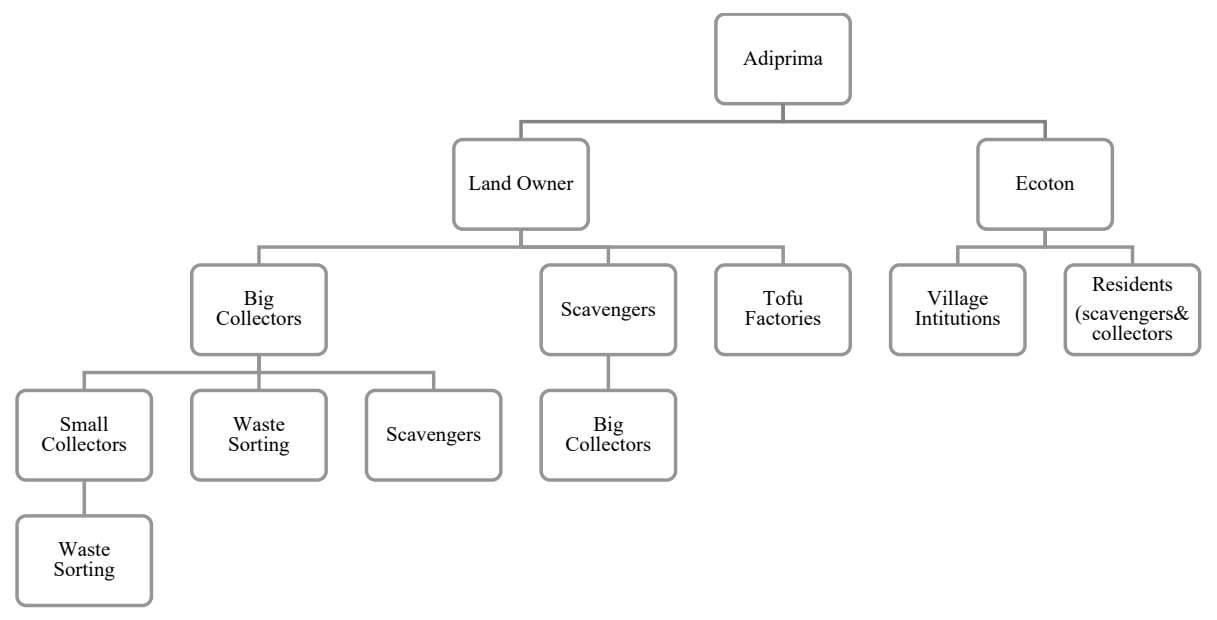

The impact resulting from dumping garbage into the hamlet is in the form of air pollution from the smoke of burning garbage, a decrease in soil quality due to garbage hoarding, flooding caused by garbage being dumped into rivers, and doctrine substances generated from combustion smoke which can interfere with human health. And the impact of the impact this is why Ecoton NGOs raised the issue to the media. In addition, Ecoton also carried out a campaign by writing petitions about imported waste, writing to the government and protesting to the embassies of countries sending waste to Indonesia. It takes about a year to get rid of imported waste from the village. During that time, Ecoton rarely had direct contact with the community, to avoid conflict between the two. This is motivated by the different views between residents and Ecoton in responding to the arrival of garbage, so that residents conclude that Ecoton is bad for them.

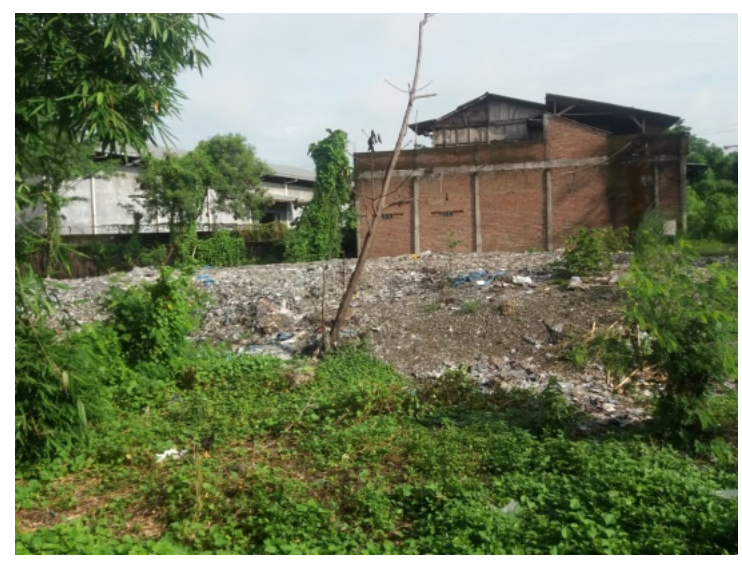

Fig. 13. The condition of the former landfill, which is buried in garbage. 
Now the condition of the village has changed, such as the former landfill that has been flattened and the soil structure has changed due to the accumulation of garbage over a long period of time. Other changes can be seen from residents who are accustomed to living side by side with garbage. Residents who formerly worked as scavengers or garbage collectors are forced to leave the profession, and chose to work odd jobs or work as farmers.

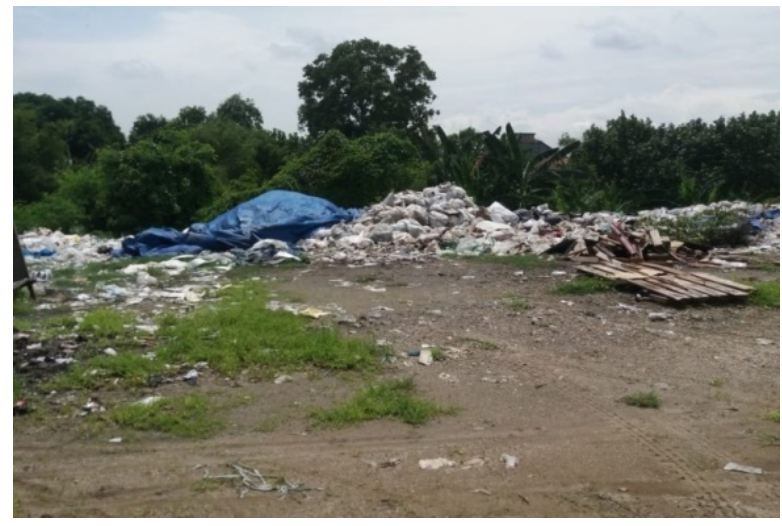

Fig. 14. Condition of the pile of waste that is no longer processed.

Another change felt by collectors is that there are many places for collecting which are closed after the raw materials (waste) are no longer disposed of in the hamlet. It can be seen from the picture above that shows a pile of imported waste that is not processed by collectors, because there is no rotation of raw materials. However, there are also other collectors who change raw materials to local waste. This garbage is obtained from collectors from other villages or scavengers from the roadside.

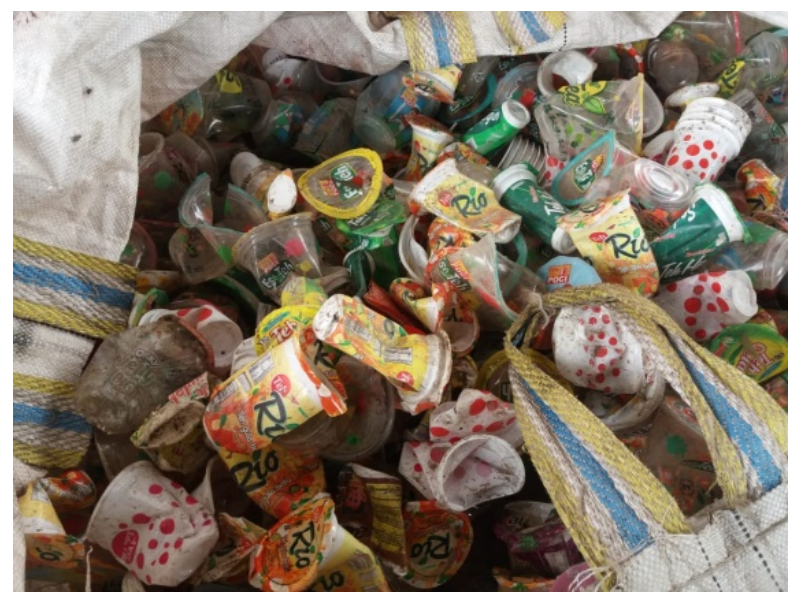

Fig. 15. Example of local waste.

The loss of rubbish that has made residents comfortable in the past ten years has had a socio-economic impact on people's lives. And the environmental impacts due to waste. 
Residents who used to earn daily income from scavenging or collecting garbage now have to return to their previous professions, namely factory workers, farmers and housewives.

\section{Conclusion}

With this, it can be concluded that the people of Sumengko Village, Gresik consider imported waste to be more valuable than local waste. The perception that imported waste has an impact on the use of imported waste in a larger amount, indirectly sending this waste will take a long time. This certainly has an impact on waste handling actions that have to work twice, namely, handling imported and local waste.

\section{References}

[1] A. P. Anggraini, "Indonesia Jadi Tujuan Ekspor Sampah Plastik Negara Maju? Ini Bahayanya," Kompas.com, 2019. .

[2] A. Azmi, "Sampah Impor Juga Ada di Gresik," Times Indonesia, 2019. .

[3] A. Bryman, Social research methods. Oxford university press, 2016.

[4] A. Adhi, "Daftar Lengkap UMK Surabaya 2018, UMK Malang 2018, UMK Gresik 2018 dan UMK Jatim 2018," Tribunnews.com, 2017. .

[5] P. Riski, "Dilema Sampah Plastik Impor, Antara Peluang dan Ancaman," VOA Indonesia, 2019. [Online]. Available: https://www.voaindonesia.com/a/dilema-sampah-plastik-impor-antarapeluang-dan-ancaman/4762069.html.

[6] J. C. Ribot and N. L. Peluso, “A theory of access,” Rural Sociol., vol. 68, no. 2, pp. 153-181, 2003.

[7] A. S. Nugroho, R. B. Sularto, and B. Wisaksono, "Tinjauan Kriminologis Tindak Premanisme Oleh Pengamen Di Simpang Lima Kota Semarang,” Diponegoro Law J., vol. 6, no. 1, pp. 1-19, 2017.

[8] J. Pretty and H. Ward, "Social capital and the environment," World Dev., vol. 29, no. 2, pp. 209227, 2001.

[9] R. Putnam, "Social capital: Measurement and consequences," Can. J. policy Res., vol. 2, no. 1, pp. 41-51, 2001.

[10] E. Suryanegara and H. Hikmah, "Hubungan Patron-Klien pada Usaha Budidaya Udang Windu (Penaeus monodon) dan Bandeng (Chanos chanos) di Kabupaten Indramayu, Jawa Barat," Bul. Ilm. Mar. Sos. Ekon. Kelaut. dan Perikan., vol. 7, no. 2, pp. 35-40, 2012.

[11] J. C. SCOTT, "Domination en the Arts of Resistance. Hidden Transcripts, New Haven and London, Yale University Press, 253p,” 1990. 